DOE/IG-0004
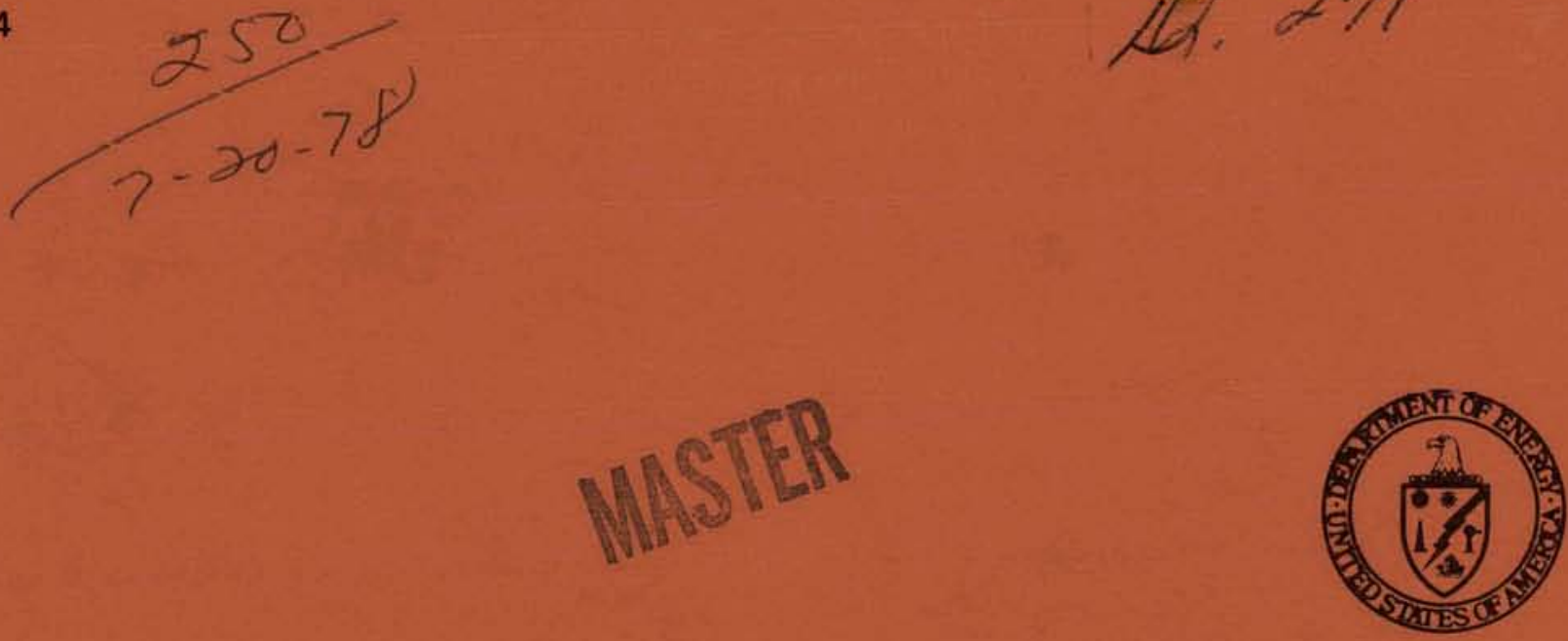

\title{
REPORT ON AUDIT OF STORES INVENTORY ACTIVITIES
}

June 1978

\section{U.S. Department of Energy} Office of Inspector General Assistant Inspector General for Audit 


\section{DISCLAIMER}

This report was prepared as an account of work sponsored by an agency of the United States Government. Neither the United States Government nor any agency Thereof, nor any of their employees, makes any warranty, express or implied, or assumes any legal liability or responsibility for the accuracy, completeness, or usefulness of any information, apparatus, product, or process disclosed, or represents that its use would not infringe privately owned rights. Reference herein to any specific commercial product, process, or service by trade name, trademark, manufacturer, or otherwise does not necessarily constitute or imply its endorsement, recommendation, or favoring by the United States Government or any agency thereof. The views and opinions of authors expressed herein do not necessarily state or reflect those of the United States Government or any agency thereof. 


\section{DISCLAIMER}

Portions of this document may be illegible in electronic image products. Images are produced from the best available original document. 

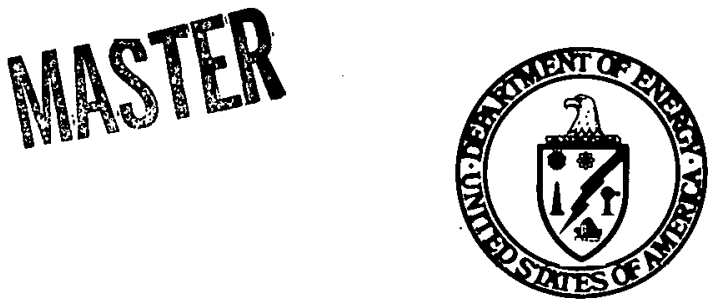

\section{REPORT ON AUDIT OF STORES INVENTORY ACTIVITIES}

June 1978

copont was prepared as an account of work

sponsored by the United States Govemment. Neither the

United States nor the United States Department of

Energy, nor any of their employees, nor any of their

contractors, subcontractors, or their employees, makes

any warranty, express or implied, or assumes any legal

liability or responsibility for the eceuracy, completeness

or usefulness of any information, apparntus, product or

process disclosed, or represents that its use would no infringe privately owned rights.

U.S. Department of Energy Office of Inspector General Assistant Inspector General for Audit Washington DC 20545 
Avallable from:

National Technical Information Service (NTIS)

U.S. Department of Commerce

5285 Port Royal Road

Springfield, Virginia 22161

Price:

Printed Copy:

Microfiche:

$\$ 4.00$

$\$ 3.00$ 
Presented herewith is a summary of the principal findings steming from audits of stores inventory activities that were conducted at 22 ERDA (nOw DOE and hereinafter referred to as DOE) contractor locations during FY 1977 . Attachment I contains a listing of the contractor locations where the audits were performed.

The primary purpose of the audits was to determine the adequacy of procedures and practices for assuring that stores inventories are being maintained at the most economical levels consistent with program requirements. Particular attention was given to the justification for adding new items and retaining existing items, and to the basis for the quantities of stores to be purchased.

\section{BACKGROUND}

- In September 1970, a report was issued on the results of an agency-wide audit of stores inventory activities. The report indicated that there were a number of weaknesses in the management of stores inventories relating to adding new items, retaining unneeded items, and establishing quantities to be purchased. As a result, a significant percentage of the total stores inventory of $\$ 90$ million was in long supply or had had no usage during the prior 12 months.

Since the 1970 audit, there has been a steady and significant increase in the dollar value of stores inventories, due in part to factors such as inflation and management decisions to reclassify equipment items as stores inventory. At the end of fiscal year 1975, the value was $\$ 158$ million. A year later, the value increased to $\$ 196$ million. By the end of fiscal year 1977 , the value had $\mathrm{r}$ isen to $\$ 210$ million.

In view of the magnitude and nature of the prior audit findings and the continuing increase in the dollar value of stores inventory, we decided that another audit in this area was desirable. Field office audit directors were therefore requested to conduct reviews in this area sometime during FY 1977, with the timing and coverage left to their discretion, based upon local conditions. All were asked, however, to evaluate the adeguacy of the procedures and practices relating to:

1. The justification for adding new items to the inventory, including review and approval by higher authority.

2. The identification of long supply and no usage (no issuance from storage during a specific period of time) items, and the justification for their retention. 
3. The appropr iateness of quantities purchased, in light of past. usage, amount on hand, and projections for future needs.

The sections that follow summarize the more significant findings noted in the FY 1977 reviews together with the overall conclusions to be drawn from these findings and related recommendations.

\section{AUDIT FINDINGS}

Adding New Items - In order to assure that inventories on hand will meet current needs without being excessive to those needs, one essential step is to provide for prior review, approval, and written justification for proposed new items before they can be added to the inventory.

The procedures at most locations covered by the audit were adequate in this regard. However, the audit did disclose single instances of the following deficiencies:

1. The written procedures did not require a written justification as to the need for new items.

2. New items were added to the stores inventory on the basis of oral requests from employees, and the requests were not being reviewed and approved by supervisors knowledgeable of program requirements.

3. The designated request form for adding new items was not being properly completed, nor was appropriate approval being obtained.

Retaining Existing Items - Another step that is necessary to effectively control inventory levels is to periodically ascertain that the items being retained in inventory continue to be needed to meet current requirements, and to promptly dispose of items that are no longer needed.

The audit disclosed that manual systems used by two contractors to identify slow-moving items were ineffective, due to the large number of stores items. Another contractor's inventory reporting system did not include spare parts control, with the result that some spare parts were overstocked.

The more significant problems, however, concerned the handling of items that had been identified as slow-moving. For example, 15 percent of one contractor's inventory, which was valued at $\$ 1.5 \mathrm{million}$, had not had any usage for at least one year. The department with the most inactive items was provided with a "no usage" report which indicated that 628 of its items $f$ it that category. After review by the department, 450 of the 628 items were designated 
for retention but no written justification was provided. Furthermore, while the other 178 items were to be written off the records and disposed of, action had been taken on only a few items at the time of the audit three months later.

In another instance, the guantities on hand for about half of 15,000 stores inventory items valued at $\$ 3.4 \mathrm{mill}$ ion were equal to one year's supply or more. An earlier audit report had recommended that a combined review by functionally responsible departments be performed of non-moving and slowmoving items to justify the retention of necessary materials and authorize disposition of excess materials. The contractor had agreed with the audit recommendation but had not established the review team at the time of the current audit which took place more than three years after the earlier audit.

In total, 13 of the contractors covered by the audit were either not making timely reviews of the continued need for stores inventory items identified as slow-moving or were not justifying the decision to retain such items. Failure to take such steps increases the likelihood of unneeded items remaining in the inventory, with resultant increased costs for financing, storage, recordkeeping, physical inventory taking and safeguarding of inventories, and increased losses through deterioration and obsolescence.

Quantities Purchased - In order to avoid excessive quantities on hand, a realistic basis must be used for determining the quantities to be purchased. Consideration must be given to such factors as past usage, amount on hand, and projections for future needs. To the extent practicable, contractors are encouraged by DOE policy to use the economic order quantity (EOQ) principle of stock replenishment. Through the use of the EOQ, which is based on the costs of buying and holding stocks, funds utilization is maximized by providing for the ordering of stocks at optimum economic levels consistent with current needs.

Most of the contractors covered in the audit were using some form of EOQ system for determining quantities to be ordered and most were considered to be reasonably satisfactory by audit. Nevertheless, weaknesses were found in some of the systems which could result in the quantity ordered varying from that considered to be the most economical. The types of weaknesses disclosed were as follows:

1. Cost factors were not reviewed. The reorder guantity was determined through an EOQ formula which included the cost ratio between the cost to order an item and the holding cost per dollar of inventory. The cost factor had not been reviewed for at least one year; thus, there was no assurance that the EOQ computations were based on current cost data. 
2. Cost data used was not used accurately (erroneous computations) or was not properly classified (ordering costs were classified as holding costs). As a result, the EOQ wás incorrect.

3. Where complex systems were in use, consisting of a number of interrelated elements, the feedback to indicate whether adjustments were needed to the elements of the system (e.g., service levels, order points, usage forecasting) was inadequate.

Statistical Data - The usual effect of weaknesses in controls over adding new items, retaining existing items, and purchasing economical guantities is an increase in the quantities of long supply and no-usage items on hand. Statisical data pertaining to such items was included in some of the individual audit reports, although not necessarily in a uniform manner. Notwithstanding the variations, the data revealed significant amounts of inactive items in stores inventories. Examples of the more significant amounts are presented below:

1. Of one contractor's total stores inventory of $\$ 6.2 \mathrm{mill}$ ion, the amount of no-usage items in the prior 12 months was $\$ 2.1$ million and the amount of items with more than 24 months' supply on hand was $\$ 1.1$ million.

2. Another contractor had $\$ 2.9 \mathrm{million}$ in stores inventory, of which $\$ 1.4$ million was in long-supply items (current quantities on hand exceeding prior 12-month withdrawals), and $\$ 1.0$ million in inventory line items with no issues during the past 12 months.

3. Using a 24-month criterion, 34 percent of a third contractor's stores inventory of $\$ 21.7 \mathrm{million}$ was either in long supply or inactive.

4. The overstocked portion of long supply (more than 48 months' supply) items of a fourth contractor's inventory was $\$ 311,647$. No-usage items were valued at $\$ 90,551$. The total stores inventory was $\$ 1,465,658$.

5. As of December 31,1976 , a fifth contractor had 1,777 nousage items for the previous 12 months with a total value of $\$ 239,131$ out of a total inventory of over $\$ 4.5 \mathrm{mill}$ ion. A special report prepared six months later indicated that the value of long-supply (more than 48 months' supply) items was $\$ 291,726$ at that time. 
6. The value of no-usage items (no issuances for more than 18 months) in a sixth contractor's stores inventory was $\$ 281,000$ out of a total of slightly over $\$ 4$ million. A review of $\$ 3.4$ million of the stores inventory total indicated the value of items with more than 12 months' supply on hand was $\$ 1.9$ million.

While retention of a significant portion of the slow-moving or inactive items would likely be justified, since special process spares and spare parts are included in the amounts, the statistical data does suggest that sizeable guantities of stores inventories. currently on hand may no longer be needed. Further retention of these unnecessary items could result in the types of increased costs discussed previously.

As noted earlier, except for the three areas 1 isted on page 1-2, the particular inventory matters to be covered at each contractor location were left to the judgment of the cognizant audit director. The findings that follow resulted from this "non-uniform" part of the audit; thus, the frequency of occurrence of a given problem area cannot be related to the group as a whole since the area in question may not have been covered at all locations.

Financial Controls - To provide adequate financial control over stores inventories, it is important that the records pertaining to inventory balances be kept current and accurate; that periodic physical inventories be taken and reconciled to stock records and accounting records; and that the stores inventories be correctly classified.

The audit disclosed one or more of the following deficiencies at eight contractor locations:

1. Physical inventories were not taken with the frequency prescribed by DOE and contractor procedures.

2. Quantities on hand for numerous inventory items were out-ofbalance with stock records, one reason being that some withdrawals had not been recorded. Also, quantities recorded as being on order were, in fact, not on order.

3. Inconsistencies existed between stock records and related quantities in the accounting records.

4. Items were misclassified among various categories of stores inventory and between stores inventory and equipment.

Physical Controls - Another element of control directly associated with physical inventories and inventory records is the control over stores items while they are in a warehouse or other holding facility, and the manner in which 
stores items are issued to the employees. Care must be taken that the items are properly segregated and protected, and that the issuances are for valid purposes.

The audit disclosed that some aspect of physical control needed to be improved at seven locations.

1. Controls over inventory withdrawals during overtime hours were lacking at two locations, and controls over the use of bench stocks were lacking at another location.

2. The storage warehouse for stores inventories was outside the secured area at one location, while at another the large sliding door in front of the stock bins and receiving area was left open during working hours. Under these conditions, unauthor ized removals of stock are more likely.

3. "Free-issue" items (i.e., no record is maintained of each issuance) needed to be put under more control in order to avoid excessive usage resulting in stock-outs.

4. A sign, indicating U.S. Government property, had not been affixed to all warehouses and storage areas, thus the deterrent of Federal prosecution of illegal entry was not made known.

5. Materials to be returned to vendors for credit had not been segregated in the warehouse, which could result in inaccurate physical inventories, improper usage, or delays in processing the returns.

\section{Conclusions and Recomendations}

While weaknesses in procedures or practices, relating to particular elements of inventory management, were disclosed at some locations, the audit results, when viewed as a whole, indicated that most of the features of inventory management covered by the audit (adding new items, replenishment, financial controls and physical controls) were being performed in a generally satisfactory manner. On the other hand, many contractors were not taking prompt action to determine the disposition of items that had been identified as slow-moving.

The statistical data developed on long-supply and no-usage items strongly suggests that the number one problem is that items with little or no likelihood of future use continue to be retained in inventory.

The principal arguments for retention of unneeded items are the cost in time and manpower that would be incurred to identify and dispose of them and the small return on the dollar that is usually received against the high cost or detrimental effect that would be incurred if it happened that the item was needed in the future. 
This line of reasoning overlooks the fact that major continuing costs are involved in physical protection, accountability, tying up capital and the like.

In view of the many program changes that have occurred in recent years and are continuing to occur; the combining of many diverse elements in DOE; and the sizeable increase in stores inventories that has taken place, we recommend that a concerted, one-time effort be undertaken under a uniform program developed and directed by the Property and Eguipment Management Branch, Directorate of Procurement and Contracts Management, HQ. The objective of this program would be to weed out and dispose of unnecessary stores inventory items which, past experience and current audits indicate, are likely to be many millions of dollars.

Additionally, we are providing copies of this report to field office managers with the recommendation that they forward it to all of their operating contractors for information and use in evaluating the adequacy of their own inventory management procedures and practices. 
Office and Contractor

Albuquergue operations office

The Bendix Corporation, Kansas City Division

General Electric Company, Neutron Devices Department

Los Alamos Scientific Laboratory

Mason \& Hanger - Silas Mason Co., Inc.

Monsanto Research Corporation

Rockwell International Corporation, Atomics International Division

Sandia Laboratories

Chicago Operations Office

Ames Laboratory

Brookhaven National Laboratory

Fermi National Accelerator Laboratory

Idaho Operations Office

EG\&G Idaho, Inc.

Nevada Operations Office

EG\&G, Inc.:

Energy Measurements Group, Las Vegas Control Group Operations, Los Alamos Contract Group Operations, San Ramon

Holmes \& Narver, Inc. - Pacific Test Division

Reynolds Electrical \& Engineering Co., Inc.

Oak Ridge Operations Office

Goodyear Atomic Corporation

National Lead Company of Ohio

Union Carbide Corporation, Nuclear Division

San Francisco Operations Office

Lawrence Berkeley Laboratory

Lawrence Livermore Laboratory

Savannah River Operations Office

E. I. duPont de Nemours and Company 